MS36-P04

\section{Organoruthenium complexes containing allylphosphite ligand}

Nuria Álvarez Pazos ${ }^{1}$

1. Departamento de Química Inorgánica, Universidade de Vigo, Vigo, Spain

email: nualvarez@uvigo.es

The reaction of the ruthenium(II) complexes $\left[\mathrm{RuCp} \mathrm{Cl}^{\prime}\left(\mathrm{PPh}_{3}\right)_{2}\right]\left(\mathrm{Cp}^{\prime}=\eta^{5}-\mathrm{C}_{5} \mathrm{H}_{5}\right.$ or $\left.\eta^{5}-\mathrm{C}_{9} \mathrm{H}_{7}\right)$ with an excess of allyldiphenylphosphite leads to the neutral complexes $\quad\left[\mathrm{Ru}\left(\eta^{5}-\mathrm{C}_{5} \mathrm{H}_{5}\right) \mathrm{Cl}\left(\mathrm{k}^{3}(P, C, C)-\mathrm{PPh}_{2} \mathrm{OCH}_{2} \mathrm{CH}=\mathrm{CH}_{2}\right)\right]$ (1a), $\left[\mathrm{Ru}\left(\eta^{5}-\mathrm{C}_{5} \mathrm{H}_{5}\right) \mathrm{Cl}\left(\mathrm{k}^{1}(\mathrm{P})-\mathrm{PPh}_{2} \mathrm{OCH}_{2} \mathrm{CH}=\mathrm{CH}_{2}\right)_{2}\right]$ (1b) and $\left[\mathrm{Ru}\left(\eta^{5}-\mathrm{C}_{9} \mathrm{H}_{7}\right) \mathrm{Cl}\left(\mathrm{k}^{1}(\mathrm{P})-\mathrm{PPh}_{2} \mathrm{OCH}_{2} \mathrm{CH}=\mathrm{CH}_{2}\right)_{2}\right](\mathbf{2 a})$. The molecular structure of the new ruthenium complexes $\mathbf{1 a}, \mathbf{1 b}$ and 2a have been determined by X-Ray diffraction. In the complex 1a the phosphite ligand is bonded to the ruthenium through the phosphorous and the $\mathrm{C}-\mathrm{C}$ double bond. On the other hand in compounds $\mathbf{1} \mathbf{b}$ and $\mathbf{2} \mathbf{a}$ the ligand is bonded to the metal centre only through the phosphorous atom.

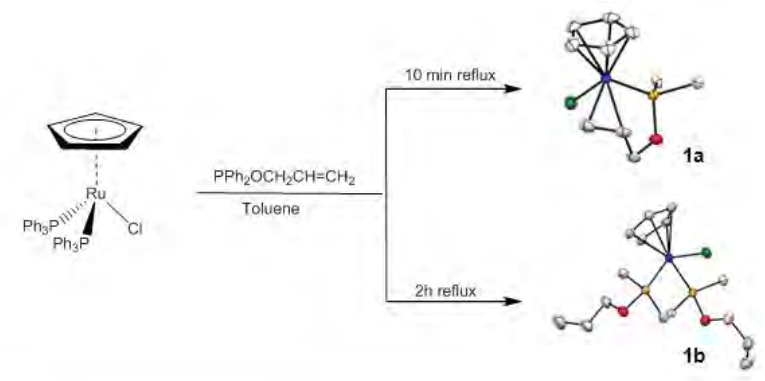

Figure: Synthesis and structure of complexes $1 a$ and $1 b$.

References:

1Díez, J.; Gamasa, M. P.; Gimeno, J.; Lastra, E.; Villar, A.

Organometallics 2005, 24, 1410-1418.

2Álvarez, P.; Lastra, E.; Gimeno, J.; Braña, P.; Sordo, J. A.; Gomez, J.; Falvello, L. R.; Bassetti, M. Organometallics 2004, 23, 29562966.

Keywords: Allylphosphite, ruthenium,
MS36-P05

\section{In situ XRD and EXAFS/XANES study of $\mathrm{xCuO}-\mathrm{yAl}_{2} \mathrm{O}_{3}-\mathrm{ZFe}_{2} \mathrm{O}_{3}$ catalyst in reaction of CO oxidation}

Olga Bulavchenko ${ }^{1}$, Zahar Vinokurov ${ }^{1}$, Andrey Saraev ${ }^{1}$, Vasily

Kaichev $^{1}$, Alexander Fedorov ${ }^{1}$, Anna Tsapina ${ }^{1}$

1. Boreskov Institute of Catalysis SB RAS, Novosibirsk State University, Novosibirsk, Russia

email: isizy@catalysis.ru

The Fe-based catalysts have been the subject of intense research in recent decades since wide application in various fields, such as water-gas shift reactions, Fisher-Tropsh synthesis, $\mathrm{CO}$ and hydrocarbons oxidation, ammonia synthesis. We are interesting in Fe-based system as effective catalysts for $\mathrm{CO}$ oxidation of gasification products of solid fuels in fluidized bed. CO is known to be the main product of gasification of dry fuels (coal, fuel oil, firewood).

One of the ways to stabilize catalyst from sintering, increase surface area and catalytic activity is using various promoters. At the same time, the introduction of different promoters affects the performance of the catalyst, i.e. shifts the temperatures of phase transformations and forms new mixed compounds. These effects strongly depends on the nature and amount of the incorporated metal cation.

We studied the influence of the nature and amount of promoter ( $\mathrm{Al}$ and $\mathrm{Cu}$ cations) in $\mathrm{Fe}-\mathrm{O}$ catalysts on the structural, textural, redox and catalytic properties of $\mathrm{xCuO}-\mathrm{yA}-$ $\mathrm{l}_{2} \mathrm{O}_{3}-\mathrm{ZFe}_{2} \mathrm{O}_{3}$ samples in $\mathrm{CO}$ oxidation. In this work, we use in situ techniques (XRD and XANES/EXAFS) to study the behavior of catalysts and model systems under reduction in CO. Copper and aluminum can enter into iron oxide during the preparation stage, or during reduction with the formation of a solid solutions based on spinel or hematite structures [1].

Catalytic testing in the $\mathrm{CO}$ oxidation revealed the difference in catalytic properties for different modifiers. Catalysts contain $\mathrm{Fe}_{2} \mathrm{O}_{3}$, addition of $\mathrm{Al}$ atoms leads to a decrease of the oxide crystal size and copper contributes the formation of spinel structure. According to TPR- $\mathrm{H}_{2}, \mathrm{Cu}$ addition leads to improvement of reducibility of catalysts and decrease the temperatures of phase transformation.

Usually, reduction of iron oxide involves several steps including the formation of the intermediate oxides such as magnetite and wustite. The reduction of $\mathrm{Fe}_{2} \mathrm{O}_{3}$ to metallic Fe can be a two-step $\mathrm{Fe}_{2} \mathrm{O}_{3} \rightarrow \mathrm{Fe}_{3} \mathrm{O}_{4} \rightarrow \mathrm{Fe}$ or three-step $\mathrm{Fe}_{2} \mathrm{O}_{3} \rightarrow \mathrm{Fe}_{3} \mathrm{O}_{4} \rightarrow \mathrm{FeO} \rightarrow \mathrm{Fe}$ mechanisms (depending the temperature and $\mathrm{H}_{2} \mathrm{O} / \mathrm{H} 2$ ratio) and affected the formation of metastable wustite.

Our in situ study shown that, introduction of aluminum in $\mathrm{Fe}_{2} \mathrm{O}_{3}$ leads to slowing down the reduction of $\mathrm{Fe}_{2} \mathrm{O}_{3}$ to $\mathrm{Fe}_{3} \mathrm{O}_{4}$ and the appearance of reaction products $(\mathrm{FeO}$ and $\mathrm{Fe})$ at higher temperatures. The formation of the intermediate solid solution of $\mathrm{Fe}_{3-\mathrm{x}} \mathrm{Al}_{\mathrm{x}} \mathrm{O}_{4}$ and the formation in the reaction products of aluminum-containing spinel-type phases $\mathrm{FeA}$ $\mathrm{l}_{2} \mathrm{O}_{4}$ and $\mathrm{Fe}_{3-\mathrm{x}} \mathrm{Al}_{\mathrm{x}} \mathrm{O}_{4}$ are also observed. The introduction of $\mathrm{Cu}$ has an effect on the acceleration of the stage. $\mathrm{FeO} \rightarrow \mathrm{Fe}$, and has little effect on the reduction of Fe3O $4 \rightarrow \mathrm{FeO} / \mathrm{Fe}$.

Acknowledgement: This work was supported by RSF (project No. 17-73-20157). 